\title{
FinTech, Blockchain and Islamic Finance: An Extensive Literature Review
}

Submitted 08/01/20, 1st revision 30/01/20, 2nd revision 10/02/20, accepted 03/04/20

\author{
Mustafa Raza Rabbani ${ }^{1}$, Shahnawaz Khan ${ }^{2}$, Eleftherios I. Thalassinos ${ }^{3}$
}

\begin{abstract}
:
Purpose: The paper aims to review the academic research work done in the area of Islamic financial technology. The Islamic FinTech area has been classified into three broad categories of the Islamic FinTech, Islamic Financial technology opportunities and challenges, Cryptocurrency/Blockchain sharia compliance and law/regulation. Finally, the study identifies and highlights the opportunities and challenges that Islamic Financial institutions can learn from the conventional FinTech organization across the world.

Approach/Methodology/Design: The study collected 133 research studies (50 from Social Science Research Network (SSRN), 30 from Research gate, 33 from Google Scholar and 20 from other sources) in the area of Islamic Financial Technology. The study presents the systematic review of the above studies.

Findings: The study classifies the Islamic FinTech into three broad categories namely, Islamic FinTech opportunities and challenges, Cryptocurrency/Blockchain sharia compliance and law/regulation. The study identifies that the sharia compliance related to the cryptocurrency/Blockchain is the biggest challenge which Islamic FinTech organizations are facing. During our review we also find that Islamic FinTech organizations are to be considered as partners by the Islamic Financial Institutions (IFI's) than the competitors. If Islamic Financial institutions want to increase efficiency, transparency and customer satisfaction they have to adopt FinTech and become partners with the FinTech companies.

Practical Implications: The study will contribute positively to the understanding of Islamic Fintech for the academia, industry, regulators, investors and other FinTech users.

Originality/Value: The study believes to contribute positively to understanding of Fintech based technology like cryptocurrency/Blockchain from sharia perspective.
\end{abstract}

Keywords: Blockchain, cryptocurrency, FinTech, Islamic finance, Sharia compliance.

JEL classification: 615, G32.

Paper Type: Literature review study.

\footnotetext{
${ }^{l}$ Department of Finance and Accounting, College of Business Administration, Kingdom University, Bahrain,e-mail: m.rabbani@ku.edu.bh

${ }^{2}$ Department of Information Technology, University College of Bahrain, Bahrain,

e-mail:skhan@ucb.edu.bh

${ }^{3}$ Professor, University of Pireaus, Affiliate Professor University of Malta, e-mail: thalassinos@ersj.eu
} 


\section{Introduction}

Financial technology is one of the most widespread term used for research in finance industry in present time. Financial Technology (FinTech) is the use of modern innovative technology in the field of finance. It is basically the use of innovative and disruptive technology for providing the financial services. Fintech as a concept peaked up the in the late 2010s (Haddad, 2018). Fintech catered to this need of more security for the investors by providing innovative and secured financial services. The other reason for the emergence of Fintech could be attributed to the need for the financial services at more affordable cost which provides mobility and faster pace (Anikina et al., 2016). The primary reason for the emergence of FinTech has been the global financial crisis of 2008 (Haddad, 2018). Global Financial crisis was the period where people lost confidence in the financial system and were looking for something which gives them more assurance in terms of their investment. The severity of financial crisis in 2008 has laid the way for Islamic Financial systems to emerge as the vehicle of recovery from financial crisis (Hussain, 2010).

The answer to the reason why FinTech is happening now is that FinTech innovations are more genuine and they are unlike the previous innovations in the financial services (Rupeika-Apoga et al., 2018: Thalassinos et al., 2015a; 2015b). These innovations are changing the lives of the people and they associated the common people they are genuine, having an infrastructure effect (Schindle, 2017). Islamic FinTech (Financial technology) is any Fintech catering to the needs of the Islamic financial institutions and are designed to asper the principles laid down by sharia. The paper aims to review the academic research work done in the area of Islamic financial technology. The Islamic FinTech area has been classified into three broad categories of the Islamic FinTech, Islamic Financial technology opportunities and challenges, Cryptocurrency/Blockchain sharia compliance and law/regulation.

It is estimated that the global cumulative investment in FinTech will exceed $\$ 1.5$ billion in the next 3-5 years (PWC, 2019). Banks and financial institutions across the world are facing the most difficult time as there is lack of innovation in banking and finance industry (Tornjanski et al., 2015; Alt, 2018; Thalassinos, 2008; Thalassinos et al., 2010; 2014; Jędrzejowska-Schiffauer et al., 2019) and FinTech has come as a blessing in disguise for these organizations as it provides more opportunities with enough innovation and tech-based services (Dapp, 2015). There is still no consensus about the term FinTech, still some of the most popular definitions of FinTech is summarized as follows:

FinTech as a term emerged in 1972 by Abraham Leo Bettinger by saying "FinTech can be defined as a contraction which combines bank experience and expertise with information technology" (Bettinger, 1972). Schueffel (2017) said "FinTech is the new term in finance industry and objective of which is to improve the financial services through the use of technology". Milian et al. (2019) mentioned that "FinTech is a thrill or hype in the media or an important innovation which can be 
attributed to the field of finance". According to IOSCO (2017) "it is the innovative business models that that can transform the finance industry". Oxford Dictionary defines "FinTech is the traditional financial services provided through the use of information technology". In the words of Dorfeitner et al. (2017) "FinTech is basically the composition of companies or group of companies providing the modern, innovative and financial services through technologies" while Sanicola (2019) said "FinTech is about both, promoting the technology to enhance the use of financial and also about the promotion and growth of digital consulting".

However, from the definitions mentioned above, from the authors' perspective, definitions cover only some of the aspects of the activities which are using financial technologies. FinTech can be defined as following: "FinTech is the fusion of Information Technology and Finance for providing the financial services at an affordable cost with a seamless user experience".

\section{Islamic FinTech Opportunities and Challenges}

The future of Islamic finance especially Islamic FinTech is very good in Muslim countries. The development of mobile and smartphone has paved way for the growth of FinTech in these countries. Of course, these opportunities are not without challenges the biggest challenge for the Islamic FinTech companies are about regulation and lack of good and authentic research in the Islamic Fintech sector (Brian, 2017; Firmansyah and Anwar, 2019). Another study (Firmansyah and Ramdani, 2018) argued that the presence of Islamic Fintech companies can help the startups in an effective way. It will be a good boost for the young graduates as there is a lack of organizations who support the young graduate aspirants with sharia compliance financing.

Fintech has grown at the double pace in the European region, in fact, at a twice rate than the Silicon Valley since 2008. Since, 2011 the volume of FinTech deals in London region has increased by three times and is more than $50 \%$ of the all European activity (Skan, 2014). There is a scope for the new financial technology companies, and it can be achieved through the wide range of financial services and respect from the clients. It is very critical for the development of financial services companies and banks as development and growth of FinTech companies will give an option to the customers to use both traditional financial services as well as new and innovative services provided through the FinTech companies (Gomber, 2018; 2017; Saksonova and Merlino, 2017). The FinTech companies have given traditional banks a lifeline to go digital and provide financial services at a low cost. In a country like Czech Republic the low-cost banking with Fintech will help the banks to compete with the larger and more established banks (Hes and Jilkova, 2016).

Islamic FinTech is based on the ethos and value of Sharia and it has the ability to lead the finance world across the globe. The biggest advantage with the Islamic Fintech is that it is transparent, accessible and easy to use (Laldin, 2018; 
Wintermeyer, 2017). The global financial crisis has not affected the financial performance of the Islamic banks because of the nature of the Islamic finance, it has emerged as an alternative to the conventional finance. With the emergence of Islamic FinTech, it provides Islamic banks an opportunity to make the finance world better and emerge as an alternative finance with more transparency and ethical values (Satyawati et al., 2017). Technological changes are just the beginning of the things to come the innovation in finance and banking industry (Arize et al., 2018). It is really important for the Islamic financial institutions to be prepared and embrace the changes. Sharia compliance Islamic FinTech has the capability to attract 150 million new customers in the next 3 years (Wonglimpiyarat, 2017; Chen, 2018).

However, it is expected to grow further as we are expecting the explosion in the growth of Muslim population as the Muslim population is expected to reach 3 billion by 2060 (Cooper, 2018). Till that date, Malaysia, UK and Indonesia are holding the first three position in terms of Islamic FinTech startups (Cooper, 2018). Another study (Rusydiana, 2018) concluded that the biggest obstacle for developing the Islamic FinTech has been the lack of trained human personnel and clear policy from the government. Researchers further states that to develop a proper ecosystem for the development of Islamic FinTech in the country the government has to bring proper regulation, educational intuitions have to bring good researches and provide trained personnel. The success of Islamic Fintech can be associated to the number of financial service areas where FinTech can be linked to, for example, it can be linked to the cryptocurrencies, blockchain and other areas such as cross border payments (Gambler, 2018; Michalopoulos and Tsermenidis, 2018). Islamic FinTech needs to keep itself at pace with the rapid development going in the conventional finance world. In fact, the opportunities for Islamic finance is more than the conventional finance because the basic concept of FinTech-shared capital is in accordance with the rules prescribed by the sharia. Islamic FinTech has the same values and ethics which are the basics of Islamic Finance (Alam, 2019a; Haqqi, 2018).

The development of Islamic Fintech provides great opportunities for the developing countries, as it provides the cost-effective solution to the financial services. At the same time, it also tests the regulating bodies to maintain the stability and to protect the investors and institutions from the fraudulent trade practices (Saba, 2019). In order to make sure that Islamic FinTech is growing and having sustainable development, an awareness program among the university students can be started among those who are using the technologies (Saad, 2019). If Fintech want to be relevant in the longer period of time, it must be innovative as adoption of FinTech by the Islamic financial institutions are not only affecting the Muslim community, but it also affects the non-Muslims and global finance world (Irfan, 2019).

Fintech has become a challenge for the financial institutions which can be turned into opportunities by making FinTech companies partners in providing innovative services than treating them as competitors (Cristea and Thalassinos, 2016; Thalassinos and Thalassinos, 2006). The main risk associated with the development 
of FinTech is that banks are exposed at every level (Anil, 2019; Romanova and Kudinska, 2017; Rabbani, 2016). FinTech is still new and the firms are not able to make sure how much investments are worth investing as far as Fintech projects are concerned (Lee, 2018). To overcome this challenge, banks and Fintech firms needs to sit together and integrate and evaluate their efforts. The Fintech and banks are needed to evaluate their value proposition in terms of integrating innovation and FinTech (Coates, 2015; Drasch et al., 2018). The opportunities and challenges of Islamic Fintech are summarized as in the following Table 1.

\section{Table 1. Islamic FinTech Opportunities and Challenges}

\begin{tabular}{|l|l|}
\hline Islamic FinTech Opportunities & Islamic FinTech Challenges \\
\hline $\begin{array}{l}\text { Islamic Fintech companies can help the } \\
\text { new startups in a big way }\end{array}$ & $\begin{array}{l}\text { Lack of good and authentic research in the } \\
\text { Islamic Fintech sector. }\end{array}$ \\
\hline $\begin{array}{l}\text { Islamic FinTech companies can provide a } \\
\text { wide range of innovative products and } \\
\text { services. }\end{array}$ & $\begin{array}{l}\text { Developing the Islamic FinTech has been } \\
\text { the lack of trained human personnel and } \\
\text { clear policy from the government. }\end{array}$ \\
\hline $\begin{array}{l}\text { It provides an option to the customers to } \\
\text { use both traditional financial services as } \\
\text { well as new and innovative services. }\end{array}$ & $\begin{array}{l}\text { Educational intuitions must bring good } \\
\text { researches and provide trained personnel } \\
\text { and academic researchers must provide } \\
\text { good research. }\end{array}$ \\
\hline $\begin{array}{l}\text { It can provide cost-effective solution to the } \\
\text { financial services and will give a lifeline to } \\
\text { traditional Islamic banks to go digital and } \\
\text { provide financial services at a low cost. }\end{array}$ & $\begin{array}{l}\text { Islamic FinTech needs to keep itself at pace } \\
\text { with the rapid development going in the } \\
\text { conventional finance world. }\end{array}$ \\
\hline $\begin{array}{l}\text { Islamic Fintech is transparent, accessible } \\
\text { and easy to use and can gain customer } \\
\text { confidence easily. }\end{array}$ & $\begin{array}{l}\text { Islamic FinTech must maintain the stability } \\
\text { and must protect the investors and } \\
\text { institutions from the fraudulent trade } \\
\text { practices. }\end{array}$ \\
\hline $\begin{array}{l}\text { It can be linked to the cryptocurrencies, } \\
\text { Blockchain and other areas such as cross } \\
\text { border payments. }\end{array}$ & $\begin{array}{l}\text { The banks are exposed at every level as } \\
\text { technology brings more transparency. }\end{array}$ \\
\hline $\begin{array}{l}\text { It can easily gain the confidence of Muslim } \\
\text { investors as it is in accordance with the } \\
\text { rules prescribed by the sharia. }\end{array}$ & $\begin{array}{l}\text { Since, Islamic FinTech is still new and } \\
\text { investors are not able to make sure how } \\
\text { much investments are worth investing. }\end{array}$ \\
\hline
\end{tabular}

\section{Islamic Fintech and Regulatory Challenges}

Fintech is already giving massive benefits to the users and investors. With the evergrowing competitions from the FinTech firms the service providers are forced to adopt the consumer centric approach. However, the evolution of Fintech also brings a lot of risks to the investors and regulators and they must find ways to safeguard the interest of the both, investors and consumers. For the consumer, the evolution of FinTech is a win-win situation as they are benefitting from the new and innovative financial services and existing financial services are made more competitive and affordable as well (Wijayanti, 2017; Loo, 2018). As the development of FinTech has evolved over different eras but post global financial crisis of 2008 the need for more stringent regulation was felt. Now, the focus has shifted from products or services 
delivered to the use of technology in delivering the services. Now, it posts a great challenge to the regulators and developers to make a correct balance between the benefits of the new innovations and the risk it brings (Arner, 2015; 2016; Ladin, 2017). The fast and rapid development in Fintech can be equally disruptive if it is not regulated properly (Vijayanti, 2017). As the FinTech is in its early stage of development and the impact of FinTech on various stakeholders can only be understood by using the dimensions such as regulation (Sangwan, 2019).

FinTech companies need to be more alert regarding the massive transformation going in the industry as it will impact the Fintech companies and they have to find ways to deal with these transformations (Lee and Shin, 2018). Since FinTech is at the early stage of innovation so instead of putting this into rigorous regulation, a more flexible and principle-based strategy are to be adopted.

The approach of regulatory authority should be kind and easy going to foster more innovation (Tsai and Peng, 2017). Regulatory Technology (RegTech) is the future of financial regulation as the need for regulating the FinTech companies increases the demand for RegTech will also increase. RegTech development will make the regulators to feel for developing and reconceptualization of existing FinTech regulation (CGAP, 2018; Armour, 2016). The big data approach is to be used for regulating the new FinTech organizations and new generation of RegTech organizations are needed for the online reporting and streamlining and providing the software for regulation (Treleaven, 2015; Shahnawaz, 2019). The externalities can be considered as a consequence of failure of financial market and it should be conceptualized to responsibility failure. This reconceptualization will make the government and regulating bodies to make a law that will consider this cost as internal cost (Schwarcz 2013; Rabbani 2020a).

The regulatory regime needs to be principle-based regulation to make a balance between the stability and access to the financial services provided by FinTech organizations (Tsai, 2016). It is very difficult to bring a uniform law which brings all of them under one umbrella because of the decentralized nature of the financial services provided by the FinTech organizations (Peter, 2015). Disruptive innovation has the potential to bring positive changes in the life of the people and it can be achieved if we have more relaxed, liberal and principal-based approach in regulating the Fintech organization (Anagnostopoulos, 2018).

Regulating the Islamic Fintech is a challenge, the industry has already made a target for the standardizing and developing the Islamic FinTech regulation (Natoor, 2019). As the rapid growth of fintech and Islamic FinTech continues, it provides both opportunities and threat to the policymakers and regulators. The policymakers and regulators must take into account the adoption ad acceptance of Islamic FinTech by making the proper balance between the benefit it brings as well as the threat it poses in terms of increased risk (Miskam, 2018; Rabbani, 2020b) as the sharia-based contracts are more complex than the conventional finance contracts. In fact, the 
emergence and adoption of FinTech by the Islamic financial institutions is the solution to the regulatory challenges they were facing before. It will bring more transparency and FinTech regulators can benefit from the innovations (Finnovasia, 2017). The players in the mega FinTech world constitute of banks, newly startups and FinTech companies. In most of the countries, the regulatory framework is still evolving and is in conflict with some of the existing regulations. The Islamic FinTech can benefit from all these by bringing more acceptable ways of regulation to stakeholders (Gassner and Lawrence, 2018; Financial Market Authority, 2017).

The success of Innovation in the FinTech industry lies with the transparent and clear regulation and with the introduction of new startups, banks, and financial innovation companies, the need for the formal regulation of the Fintech companies have increased (Alam et al., 2019b; MacDonagh, 2016). New and innovative technologies are to be encouraged as they benefit the consumer at large and RegTech applies to all these organizations to overcome their regulatory challenges (FCA, 2019). Rapidly growing Fintech provides a challenge to financial regulators who are already facing the challenge of regulating the financial institutions after the financial crisis. 'Regulatory Sandboxes' aims to encourage the innovations and test their innovations in the safe environment (Bromberg, 2017; Godwin 2017).

In another study related to Fintech in the European Union (EU) countries (Bajakic, 2019; Fetai, 2015; Thalassinos and Thalassinos, 2018) reveals that EU provides the platform to FinTech companies to promote innovation in the area of financial services while safeguarding the interest of the consumers and investors. The goal of EU is to empower all these companies to provide tech enabled technologies such as Big data (Shahnawaz, 2019), Artificial Intelligence (AI), blockchain and cryptocurrency. Promoting and encouraging the innovation is more than just regulating these organizations (Bijakic, 2019). Islamic fund management is embracing technology, and this is a disruption and it creates a kind of new concern for the regulators and provides the opportunities. AI has become synonyms to the Islamic fund management (Miskam, 2019). The following Table 2 summarizes the opportunities and threats for Islamic Fintech.

Table 2. Regulations and Islamic Fintech

\begin{tabular}{|l|l|}
\hline $\begin{array}{l}\text { Regulation as an opportunity for } \\
\text { boosting Islamic FinTech }\end{array}$ & $\begin{array}{l}\text { Regulation as a threat for Islamic } \\
\text { FinTech }\end{array}$ \\
\hline $\begin{array}{l}\text { The externalities can be considered because } \\
\text { of the failure of financial market and it } \\
\text { should be conceptualized to responsibility } \\
\text { failure. }\end{array}$ & $\begin{array}{l}\text { The financial regulators who are already } \\
\text { facing the challenge of regulating the } \\
\text { financial institutions after the financial } \\
\text { crisis }\end{array}$ \\
\hline $\begin{array}{l}\text { The government and regulating bodies to } \\
\text { make a law that will consider the cost of } \\
\text { regulations as an internal cost. }\end{array}$ & $\begin{array}{l}\text { The regulation brings balance between the } \\
\text { benefit it brings as well as the threat it poses } \\
\text { in terms of increased risk }\end{array}$ \\
\hline $\begin{array}{l}\text { The regulation should be relaxed, liberal } \\
\text { and principal-based approach in regulating } \\
\text { the Fintech organization. }\end{array}$ & $\begin{array}{l}\text { The regulatory framework is still evolving } \\
\text { and conflict with some of the existing } \\
\text { regulations. }\end{array}$ \\
\hline
\end{tabular}




\section{Blockchain and Islamic Finance}

Blockchain technology has gained a lot of attention and has attracted worldwide interest from a variety of stakeholders. Blockchain and artificial intelligence is the new trend for Fintech innovations. Artificial Intelligence use a variety of approaches such as artificial neural network (Khan, 2011; Shahnawaz, 2011), rule-based approach (Shahnawaz, 2013a), statistical approach (Shahnawaz, 2013b), case-based reasoning (Shahnawaz, 2015) and many more and has been used in wide range of applications such as sentiment analysis (Shahnawaz, 2017), machine translation (Khan, 2018), image processing, self-deriving automobiles, chatbot (Khan, 2020) etc. Blockchain technology has several evident advantages because of its nature and the underlying technological structure. Blockchain is a collection of linked blocks on a peer to peer network where blocks are connected using cryptographic hash code because of which there is no single point of failure. As even if a few nodes fail in the peer to peer network, other nodes will continue to work which makes blockchain more reliable to operate and maintain. Second vital feature of the blockchain is that it is digital technology which enables it to be applied in a variety of applications. Another crucial feature of blockchain is the transparency, blockchain transactions are traceable and visible to all the users of the blockchain. Immutability is another key feature of the blockchain. It is almost impossible to make any changes to the transactions on blockchain or to the blockchain. However, some very rare cases have been found for blockchain changes. Many theorists have been predicting that the financial services will be disrupted using blockchain technology in the coming future.

Blockchain is an expanding list of blocks. Each block contains transaction data, a timestamp and a cryptographic hash code of the previous block (Nakamoto, 2008). The key interesting feature of the blockchain is its resistance to data modification and trackable transactions. Therefore, blockchain, if used fairly, can be a boon to the Islamic banking and finance for providing trackable transactions and transparency. It can boost the trust in Islamic financial dealings, transfers and transactions (AbuBakar, 2018).

A Fintech study in Islamic banking discusses one of the major issues which is to find out if the agent is working in the best interest of the stakeholders. This research proposes a blockchain based monitoring process for transparency of the form and degree of accountability of the Islamic Bank (agent). Though, smart contracts still have neither been accepted legally nor have been regulated by the government in majority of the countries around the globe where Islamic Banking is available.

However, this study advocates the use of blockchain and smart contract in the agent monitoring process so that all the key stakeholders (Sharia Supervisory Boards, contributors, governmental regulators and beneficiaries) in Islamic banking can have transparency in all the agent dealing (Lacasse, 2018). If we ignore the fact of the 
legality, blockchain based monitoring process can be useful tool in Islamic Fintech (Lacasse, 2018). Smart contract transactions can create a record of ownership and assets and these transactions are immutable and trackable. As per Lawrence (2017), the use of smart contracts as replacement of the financial contracts and services cost can be minimized by up to $95 \%$ and Islamic Banking can be revolutionized. One aspect of the Islamic Finance and Banking is to contribute to the social causes. Contributors usually mandate Islamic Finance and Banking agents for this task and give them the decree for transferring contributions according to Shariah for the social causes on their behalf. There is an assumption related to agency theory that Finance and Banking agents seek to maximize their compensation and welfare. However, smart contracts can be a useful mechanism in all financial transactions and the monitoring and regulation process can be reduced to mere writing a smart contract (Lacasse, 2017).

A research study considers Blockchain management system (BMS) as an accounting system (Evans, 2015). Blockchain based systems like Bitcoin can be used as a reliable solution for various types of transactions. In Bitcoin, peer to peer network nodes verifies the transactions. The transactions are recorded in a distributed public network and linked using cryptography. The application of blockchain in the financial sector is observing new avenues in various domains every day. One of such application is in the domain of crowdfunding, a research by Muneeza (2018) discuss the application of blockchain in crowdfunding. Research suggests that the use of blockchain technology in crowdfunding can diminish the issues faced on crowdfunding platforms based on six crowdfunding platforms (Muneeza, 2018).

Fundraisers can use smart contracts or issue their own shares providing a guarantee to return pledge contributions in case funding targets are not met. This type of guarantee will help the initiators of the projects and as well as crowdfunding shareholders in securing their rights at a minimal cost (Zhu and Zhou, 2016). Some of the challenges in traditional banking are multiple intermediate, a central fund management party, high transactions cost, centralized database management and double payments etc. However, the use of the blockchain based crowdfunding system can overcome these challenges. Along with these, a blockchain based crowdfunding system can add new functionalities such as a blockchain based voting system can include shareholders and crowd in corporate governance, smart contracts can be used to detect fundraising frauds (Niforos et al., 2017; Zhu and Zho, 2016), identity management system to avoid identity theft (Niforos et al., 2017) and use of digital currency can eliminate central intermediary (Biancone, 2019; Collins and Baeck, 2015).

Blockchain technology can be used to streamline the financial transactions. Some estimates have suggested that blockchain technology can help the financial institutions to save at least $\$ 20$ billion in cross border payment, regulatory, and settlement costs (Fanning, 2016). Saadiqin is a Shariah compliant industrial financial solution and claims $80 \%$ reduction in outstanding issues, $50 \%$ reduction of your 
close-of-business times and 99\% efficiency in operation (Saadiqin, 2020). Although, integrating blockchain with existing financial solutions is not a simple task. Efforts have been made in the direction of integrating existing digital solutions with blockchain with the help of third-party software (Alidin, 2018). It can give a new direction in the use of blockchain for Islamic finance and Shariah compliant financial services. The following Table 3 outlines the major issues of Islamic Finance and advantages and some applications of using Blockchain in Islamic Fintech.

Table 3. Major issues of Islamic Finance and advantages and some applications of using Blockchain in Islamic Fintech

\begin{tabular}{|l|}
\hline \multicolumn{1}{|c|}{ Advantages } \\
\hline No single point of failure. \\
\hline It can easily detect frauds. \\
\hline $\begin{array}{l}\text { Blockchain transactions are transparent and are traceable and visible to all the users of the } \\
\text { blockchain. }\end{array}$ \\
\hline $\begin{array}{l}\text { It is almost impossible to make any changes to the transactions on blockchain or to the } \\
\text { blockchain. }\end{array}$ \\
\hline $\begin{array}{l}\text { Smart contracts can be a useful mechanism in all financial transactions and the monitoring } \\
\text { and regulation process can be reduced to mere writing a smart contract. }\end{array}$ \\
\hline Financial contracts and services cost can be minimized by up to 95\%. \\
\hline \multicolumn{1}{c|}{ Applications } \\
\hline Blockchain management system (BMS) as an accounting system. \\
\hline Domain of crowdfunding etc. \\
\hline $\begin{array}{l}\text { Major issues which is to find out if the agent is working in the best interest of the } \\
\text { stakeholders. }\end{array}$ \\
\hline Agents seeks to maximize their compensation and welfare. \\
\hline
\end{tabular}

\section{Cryptocurrency, Bitcoin and Islamic Finance}

Cryptocurrency is the electronic cash which can be used in place of the fiat money as a medium of exchange. It uses blockchain technology which provides basis for secure, trackable and immutable financial transactions. The creation of additional units is also controlled with the help of blockchain (Andy, 2011; Polansek, 2016). Cryptocurrency systems do not have a central control system unlike the traditional central banking systems and digital currency like Amazon cash etc., (Allison, 2015). One major issue every digital cash payment network has is double spending. Double spending means that the same amount has been spent twice by the same entity. In digital cash payment network, a central server keeps the balance record to stop double spending. In cryptocurrency systems, there is no centralized system, it is a decentralized network, therefore, the network keeps the history and list of all the transactions and any transactions has to be approved by the peers which eliminates the case of double spending (Ameer, 2018). 
The cryptocurrency capitalization has direct causal relationship with the bank deposits. As the investment in cryptocurrency increases the deposit in the bank account decreases. In order to remove this threat, the only option left with the bank is to offer cryptocurrency as an alternative investment offer to investors. The banks are forced to embrace the cryptocurrency as the alternative investment in portfolio diversification or they can adopt the Blockchain option to provide their customer a low cost and highly secured and ease of use investment (Othman, 2019). Bitcoin is a fairly new currency and its risks are unknown and most of the experts are of the opinion that the use of bitcoin is to be avoided (Folkinshteyn, Lennon and Reilly 2015). Virtual currency is unlike real currency and brings a lot of risk for the users and it also poses a threat to the real economy (Zahudi, 2016). Despite of the fact that bitcoin is one of the hottest properties, it has not received much attention from the scholar community. Whatever little researches has been done, it is done either on regulatory framework or on the technical aspect of the bitcoin. There is a lack of research to examine bitcoin from currency perspective. Bitcoin must be promoted or introduced as a complement to the fiat currency than the substitute to the fiat currency (Carrick, 2016).

Muslim scholars have mixed views over sharia compliance of cryptocurrencies. Some famous scholars like grand Mufti of Egypt Shaikh Shaki Alam, has out rightly rejected the cryptocurrency on the ground that it violates the basic principles of Islam that is declared haram. To be declared it halal, it must be complying with the Maqasid al sharia. Those scholars or Mufties who are declaring Cryptocurrency as haram have not understood the working of the term itself. There are more than 2800 cryptocurrencies and all of them are not currencies, they can be called as crypto assets. The coin is not the only type of crypto assets. The crypto assets do not fulfill the criteria of store of value, unit of account and medium of exchange to be called as a currency (Yakubowski, 2019). Bitcoin cannot be accepted by the sharia scholar as it provides the transactions which are prohibited by sharia.

There is an element of gharar in the bitcoin transaction as real value of currency is not known, prices are highly volatile, also there is variance in store of value and method of value. Because the fundamental principles of finance say that the gharar is against the sharia and it is haram (Abu Bakar, 2017), gharar is defined as the uncertainty, deception and risk. It is an Arabic word which is used for selling something which is yet to exist (Ahmad, 2008; Cattelan, 2009). In another study on Bitcoin and cryptocurrency it was concluded that since bitcoin lacks intrinsic value and has zero supervision of the central bank it can easily be misused. It also violates the basic principle of Islamic economics i.e., social justice, because of these reasons the bitcoin is considered as against sharia and should be prohibited (Meera, 2018).

However, according to some researchers, Bitcoin cryptocurrency is a Nobel idea in the society with ever popularity and demand for it. There is no proper evidence that the bitcoin violates the sharia principles. The record increasing price of bitcoin $(20 \mathrm{k}$ USD on Dec. 12, 2018) does not mean that it is against the sharia principles. It only 
means the growing popularity and faith of the people in the bitcoin and cryptocurrency (Oziev, 2018). Bitcoin can be discussed in two unique ways like maslaha (benefits to the society) and risk sharing rather than the risk shifting. If talk about the maslaha there are millions of muslim adults with just mobile phone and internet connection are getting benefit from it and with regarding to risk sharing bitcoin works on the principles of Musharakah where two or more persons come together in doing a business and shares the risk. As in case of Bitcoin there is a large pool of people, so risk is minimized (Evans, 2015). With the massive popularity of cryptocurrency like Bitcoin, the talks are going on whether Central Banks should issue their own digital currency named as Central Bank Digital Currency (CBDC).

With Central Banks issuing their own digital currency will provide the individuals an opportunity to open an account directly with the Central Bank and transact as legal tender (Ahmat, 2017). According to a report published in Stellar blogspot, 'Stellar' has already become the first sharia certified distributed ledger protocol. The sharia supervisory board from Bahrain has given certification and asked the financial institutions to deploy the Stellar technology in Islamic financial institutions (Alexandre, 2018). Cryptocurrency have presence of both haram and halal elements.

While declaring the cryptocurrency haram or halal it must be checked on transaction to transaction basis. It is very difficult to say that the cryptocurrency is haram as a whole (Asif, 2018). There is scope to develop the digital currency compatible with Islam using Blockchain technology. If we are able to develop a digital currency which is as per the ethos and principle of sharia, it will be a great revolution in the field of finance and technological advancement (Alzubaidi and Abdullah, 2017). Blockchain and cryptocurrency are a financial innovation and it can bring positive changes in the lives of the Muslim community, scholars should review their decision about declaring it haram (Abojeib, 2019).

There is a need to develop a new strategy for all section of society including, consumer, government, financial institution and investors to cope and understand this digital revolution. More insightful information is needed for understanding the concept of Blockchain and cryptocurrency itself (Mohamed, 2018). For a sharia scholar, it should be an ultimate objective to find ways to give benefits to all the interested Muslim community through this financial revolution. Because digital currency can take the shape of various sustainable and diversifiable projects. The investment in cryptocurrency can not only give them profit but can also change their lives for good (Noordin, 2018). The area of developing an Islamic digital currency using the blockchain technology has also been investigated by some scholars (Alzubaidi, 2017).

A significant number of cryptocurrencies is in operation in the present time. These cryptocurrencies can be of various types and may use different types of algorithms. However, for the sustainability of the cryptocurrency, it should observe all legal requirements, as of now, there is no operational procedure or standard system which 
can verify compliance with legal requirements. This is a negative aspect of cryptocurrency in the market which says that since there is no supervision, people will lose the money. For any cryptocurrency, to be a sustainable cryptocurrency, it should follow and sustain all legal requirements (Billah, 2019). The research by Ibrahim (2017) has concluded that developing an Islamic digital currency is feasible.

\section{Cryptocurrency and its Legality as per Sharia}

Islamic scholars have mixed perspective in regard to cryptocurrency, some scholars consider it permissible (halal) and some scholars consider it impermissible (haram). The views, which keep cryptocurrency into the category of permissible, state its principle and nature (Al-hussaini, 2019). There is clearly an inadequacy of Islamic laws for cryptocurrency use in any form of transactions and there is a need of a model and system for Islamic digital currency. There are views behind keeping cryptocurrency into the category of impermissible such as violation of the governmental constitution, uncertainties in the cryptocurrency implementation as revealed in many fatwas and stated by many researchers. Another reason for considering cryptocurrencies as impermissible is the uncertainty of its value because the value of cryptocurrency can fluctuate because of variety of reasons such as a system hack or a technical glitch etc., (Al-hussaini, 2019).

There are several known issues with paper-based currencies such as forgery, unlimited supply, inflation and government abuse etc. If we consider these issues, these are not in compliance with Shariah law as used in Islamic finance and banking which implies that paper-based currency is not an ideal medium of exchange. On the other hand, cryptocurrencies are more reliable, transparent, decentralized, limited in supply and highly unlikely to be hacked (forgery and abuse) (Siswantoro, 2020; Amri, 2019). Some researchers have a view related to the connectivity to the world economy, some countries are not connected to the world economy, blockchain technology and cryptocurrencies can bridge this gap and provide them the power over their own wealth and security of their wealth without relying on a central agency (Fait Muedini, 2018). However, because of digital divide many people around the world do not have access to the internet which means many people around the world won't have access to money or medium of exchange.

A research by Oziev (2017) on Shariah perspective of cryptocurrency suggests that cryptocurrency like Bitcoin can be considered permissible in certain scenarios such as in the case of currency exchange or for the making the payments for services or goods. However, because of the high instability in the exchange value of cryptocurrencies, it is not permissible to acquire them for the purpose of accumulation or for investment. According to Oziev (2017), the way of acquiring the cryptocurrency is also an important aspect in the deciding the permissibility or impermissibility, if the cryptocurrency has been acquired for the purpose of the settlement of payments for goods or services then it is permissible, however, if the cryptocurrency has been mined for saving and the miner has the intention that it will 
give high return in future, then it is nothing but speculation (maysir) and excessive risk (garar) and is impermissible. Alam et al. (2019c) discusses that a cryptocurrency can be permissible and even supported by government if it can overcome the negative aspect of it. For example, if a cryptocurrency can provide some certainty in the stability of exchange value, protection or surety from abuse of the cryptocurrency such as usage in fraudulent activities and operation under Shariah and Financial regulation, then it can be accepted as Islamic cryptocurrency.

In some of the major economies of the world such as China and Russia, cryptocurrencies are banned because of the risk and safety reasons (Siswantoro, 2020). In Islamic countries, the cryptocurrencies face another challenge which is their compliances with the Shariah law. Islamic countries such as Pakistan, Algeria, Egypt, Morocco have banned cryptocurrencies partially and, in some countries, completely. The reasons behind complete or partial ban of the cryptocurrency is its compliance with the Shariah law and Islamic teachings on which different scholars have different views. However, an important factor in permissibility or impermissibility of the cryptocurrency is the purpose of acquiring it. If the purpose of acquiring is to gain the profit then it is impermissible to own it according to majority of the scholars and if the motives behind acquiring the cryptocurrency is just to use as a medium of exchange then majority of the scholars keep it in the permissible category. The following Table 4 sum up the permissibility and impermissibility factors for Cryptocurrency as per Shariah.

Table 4. Permissibility and Impermissibility factors for Cryptocurrency as per Shariah

\begin{tabular}{|l|l|}
\hline \multicolumn{1}{|c|}{ Impermissible } & \multicolumn{1}{|c|}{ Permissible } \\
\hline $\begin{array}{l}\text { Impermissible due to violation of the } \\
\text { governmental constitution, uncertainties in } \\
\text { the cryptocurrency implementation. }\end{array}$ & $\begin{array}{l}\text { Cryptocurrency can be considered } \\
\text { permissible based on its principle and nature }\end{array}$ \\
\hline $\begin{array}{l}\text { Not permissible to acquire them for the } \\
\text { purpose of accumulation or for investment. }\end{array}$ & $\begin{array}{l}\text { Permissible in certain scenarios such as in } \\
\text { case of currency exchange or for the making } \\
\text { the payments for services or goods }\end{array}$ \\
\hline
\end{tabular}

\section{Concluding Remarks}

This study conducts a comprehensive review of the various factors of the use of Financial Technologies such as Blockchain, Cryptocurrencies in Islamic Finance. Any innovation is welcome is Islam as long as it does not violate basic teachings of the Quran and Sunnah. The prospect for Islamic Fintech is really bright in Islamic world and among the Muslim users of financial services as it provides opportunities for innovation and can provide financial services at affordable cost.

The use of FinTech in Islamic Finance or Islamic FinTech poses lot of challenges as well as it explores numerous opportunities. Islamic FinTech can give a boost to 
startups as it is transparent, accessible and easy to use and can gain customer confidence with an ease which is very important for the startups. FinTech solutions are more cost-effective in providing the financial services as compare to traditional finance and banking. Islamic FinTech will emerge as a lifeline for the Islamic Finance and Banking institution because of its cost effectiveness and the reach to the communities. Islamic FinTech can easily gain the confidence of Muslim communities as well as the non-muslim communities primarily because of its transparency. However, along with the great opportunities comes great challenges as well, such as there is a lack good and authentic research in Islamic FinTech, lack of trained human personnel, government and Shariah compliance trade-offs, cyberattacks and the confidence of the investors as Islamic FinTech is still in its infancy. Regulatory framework is another important area for Islamic FinTech which has to be regularized and overcome its flaws. As Islamic FinTech is still in its inception, there are several regulatory challenges such as regulatory framework is still evolving and are in conflict with some of the existing regulations. The regulatory bodies should use relaxed, liberal and principal-based approaches in regulating the Fintech organization.

As far as the Blockchain technology in Islamic FinTech is concerned, it gives a more secured and innovative way of doing business. The transactions under Blockchain are more transparent and visible to all the users. Also, Smart contracts can be a useful mechanism in all financial transactions and the monitoring and regulation process can be reduced to mere writing a smart contract. The Cryptocurrency has been a revelation and Muslim countries seriously needs to have to more research and must find ways to develop and a cryptocurrency fully compatible with the sharia principle. As of now no Muslim country allow cryptocurrency for legal transactions.

\section{References:}

Abojeib, M., Habib, F. 2019. Blockchain for Islamic Social Responsibility Institutions, FinTech as a Disruptive Technology for Financial Institutions. IGI Global, 221-240. Abu-Bakar, N., Sofian, R., Kiyotaka, U. 2017. Cryptocurrency Framework Diagnostics from Islamic Finance Perspective: A New Insight of Bitcoin System Transaction. International Journal of Management Science and Business Administration, 4(1), 19-28.

Abu-Bakar, M.M. 2018. Shariah Analysis of Bitcoin, Cryptocurrency and Blockchain.

Ahmad, W.M.W., Marhaini, W. 2008. Some Issues of Gharar (Uncertainty) in Insurance. Essential Readings in Islamic Finance.

Ahmat, N., Bashir, S. 2017. Central Bank Cryptocurrency: A Monetary Policy Perspective. Bank Negara Malaysia, September.

Alam N., Gupta L., Zameni, A. 2019a. Fintech Regulation. In: Fintech and Islamic Finance, 137-158. Palgrave Macmillan, Cham.

Alam, N., Gupta, L., Zameni, A. 2019b. Challenges and Success Factors for Islamic Fintech. In Fintech and Islamic Finance, 159-173. Palgrave Macmillan, Cham.

Alam, N., Gupta, L., Zameni, A. 2019c. Cryptocurrency and Islamic Finance. In Fintech and Islamic Finance, 99-118. Palgrave Macmillan, Cham. 
Alexandre, A. 2018. Stellar Becomes 'First' Shari'ah-Certified Blockchain for Payments and Asset Tokenization. In the Cointelegraph, the Future of Money, 18.

Al-hussaini, A.I.S., Ibrahim, A.A., Fauzan, M. 2019. Users Perception of Cryptocurrency System Application from the Islamic Views.

Alidin, A.A., Ali-Wosabi, A.A.A., Yusoff, Z. 2018. Overview of Blockchain Implementation on Islamic Finance: Saadiqin Experience. Cyber Resilience Conference (CRC), Putrajaya, Malaysia,1-2. doi: 10.1109/CR.2018.8626822.

Allison, I. 2015. If Banks Want Benefits of Blockchains, they Must Go Permissionless. International Business Times.

Alt, R., Beck, R., Smits, M.T. 2018. FinTech and the transformation of the financial industry. Electronic Markets, 28, 235-243. https://doi.org/10.1007/s12525-018-0310-9.

Alzubaidi, I.B., Abdullah, A. 2017. Developing a Digital Currency from an Islamic Perspective: Case of Blockchain Technology. International Business Research, 10, $1-9$.

Alzubaidi, I.B., Adam, A. 2017. Developing a Digital Currency from an Islamic Perspective: Case of Blockchain Technology. International Business Research, 10(11).

Ameer, R. 2018. What Is Cryptocurrency: 21st-Century Unicorn - or the Money of the Future? Blockgeeks.

Anagnostopoulos, Y. 2018. Fintech and Regtech: Impact on Regulators and Banks. Journal of Economics and Business, 100(10). Doi:1016/j.jeconbus.2018.07.003.

Andy, G. 2011. Crypto Currency. Forbes. Retrieved 10 Feb 2020.

Anikina, I.D., Gukova, V.A., Golodova, A.A., Chekalkina, A.A. 2016. Methodological Aspects of Prioritization of Financial Tools for Stimulation of Innovative Activities.

Anil, S.K., Alistair, M. 2019. FinTech and the future of financial services: What are the research gaps? CAMA Working Papers, Centre for Applied Macroeconomic Analysis, Crawford School of Public Policy, the Australian National University.

Arize, C.A., Andreopoulos-Campanelli, G., Kallianiotis, N.I., Malindretos, J. 2018. MNC Transactions Foreign Exchange Exposure: An Application. International Journal of Economics \& Business Administration, 6(1), 54-60.

Armour, J., Awrey, D., Davies, P., Enriques, L., Gordon, J.N., Mayer, C., Payne, J. 2016. Principles of Financial Regulation, Oxford, UK: Oxford University Press.

Arner, D.W., Barberis, J.N., Buckley, R.P. 2015. The Evolution of FinTech: A New PostCrisis Paradigm? University of Hong Kong, Faculty of Law Research Paper No. 2015/047; UNSW Law Research Paper No. 2016-62.

Arner, D.W., Barberis, J.N., Buckley, R.P. 2016. FinTech, RegTech and the Reconceptualization of Financial Regulation. Northwestern Journal of International Law \& Business.

Asif, S. 2018. The Halal and Haram Aspects of Digital Currencies in Islam, https://www.researchgate.net/publication/326398987_The_Halal_and_Haram_Aspe cts_of_DigitalCurrencies_in_Islam.

Bajakić, I. 2019. Financial Integration of the New Member States-Case Study of EU's Regulatory Initiative on Financial Technologies. doi.org/10.31410/EMAN.2019.331.

Beik, I.S., Arsyianti, L.D. 2008. Why the rate of financing in Islamic Banks is high? An analysis based on the Malaysian case. Tazkia Islamic Finance and Business Review, $3(1)$.

Bettinger, A. 1972. Fintech: A series of 40-time shared models used at manufacturers Hanover trust company. Interfaces 62-63.

Biancone, P.P., Secinaro, S., Kamal, M. 2019. Crowdfunding and Fintech: business model 
sharia-compliant. European Journal of Islamic Finance, 12.

Billah, M.M. 2019. Islamic Cryptocurrency. Islamic Financial Products, 413-434.

Brian, Y. 2017. Fintech could be solution for regulatory challenges facing Shariah contracts. International Financial Law Review. Available at: https://search.proquest.com/openview/beff0318536ed68104ec4b7be68b10af/1?pqorigsite $=$ gscholar $\& \mathrm{cbl}=36341$.

Bromberg, L.E., Godwin, A.J., Ramsay, I. 2017. Fintech Sandboxes: Achieving a Balance between Regulation and Innovation. Journal of Banking and Finance Law and Practice, 28(4), 314-336.

Carrick, J. 2016. Bitcoin as a Complement to Emerging Market Currencies. Emerging Markets Finance and Trade, 52(10), 2321-2334.

Cattelan, V. 2009. From the concept of haqq to the prohibitions of ribā, gharar and maysir in Islamic finance. Int. J. Monetary Economics and Finance, Vol. 2, Nos. 3/4.

CGAP. 2018. RegTech and Digital Finance Supervision: A Leap into the Future. Available at: https://www.cgap.org/blog/regtech-and-digital-finance-supervision-leap-future.

Chen, K. 2018. Financial Innovation and Technology Firms: A Smart New World with Machines. In Banking and Finance Issues in Emerging Markets, 279-292.

Coates, R. 2015. Chinese Shadow Banking and the Rise of the Bank of Foxconn. Supply China Management Review.

Collins, L., Baeck, P. 2015. Cryptocurrencies could bring cost-savings to crowdfunding and make it easier to hold small stakes in companies, UK: NESTA, available from: https://www.nesta.org.uk/blog/crowdfunding-and-cryptocurrencies/.

Cooper, T. 2018. The Race to Become the World's Leading Leading Islamic Fintech Hub Raconteur. Racounter. At: https://www.raconteur.net/finance/race-become-worldsleading- leading-islamic-fintech-hub.

Cristea, M., Thalassinos, I.E. 2016. Private Pension Plans: An Important Component of the Financial Market. International Journal of Economics and Business Administration 4(1), 110-115. DOI: 10.35808/ijeba/95.

Dapp, T.M. 2014. Fintech-The Digital ${ }^{\circledR}$ evolution in the Financial Sector: Algorithm-based Banking with the Human Touch.

Dorfleitner, G., Hornuf, L., Schmitt, M., Weber, M. 2017. Definition of FinTech and description of the FinTech industry. In FinTech in Germany, 5-10, Springer, Cham.

Drasch, B., Schweizer, A., Urbach, N. 2018. Integrating the 'Troublemakers': A Taxonomy for Cooperation between Banks and Fintechs. Journal of Economics and Business. 10.1016/j.jeconbus.2018.04.002.

El Amri, M.C., Mohammed, M.O. 2019. The Analysis of Cryptocurrency Based on Maqasid al-Shari'ah. In Halal Cryptocurrency Management, 119-131. Palgrave Macmillan, Cham.

Evans, C. 2015. Bitcoin in Islamic Banking and Finance. Journal of Islamic Banking and Finance, 3(1), 1-11.

Fait, M. 2018. The Compatibility of Cryptocurrencies and Islamic Finance. European Journal of Islamic Finance, 10.

Fanning, K., Centers, D.P. 2016. Blockchain and its Coming Impact on Financial Services. Journal of Corporate Accounting \& Finance, 27(5), 53-57. doi:10.1002/jcaf.22179.

FCA. 2019. RegTech Applies to New Technologies Developed to Help Overcome Regulatory Challenges in Financial Services. At: https://www.fca.org.uk/firms/regtech.

Fetai, B. 2015. Financial Integration and Financial Development: Does Financial Integration Matter? European Research Studies Journal, 18(2), 97-106. 
Financial Market Authority. 2017. Regulatory Treatment of Initial Coin Offerings (ICOs). (Accessed on 10-Feb-2020) Available at:

https://www.finma.ch/en/ /media/finma/dokumente/dokumentencenter/myfinma/4d okumentation/finma-aufsichtsmitteilungen/20170929-finma-aufsichtsmitteilung-042017.pdf

FInnovasia. 2018. HongKong FInTech week 2017. Available at: https://fintechnews.hk/2990/various/hong-kong-fintech-week-2017-day-4highlights/.

Firmansyah, E.A., Anwar, M. 2019. Islamic Financial Technology (Fintech): Its Challenges and Prospect. Advances in Social Science, Education and Humanities Research, 216. Available at: https://www.researchgate.net/publication/330923829.

Firmansyah, H.B., Ahmad, L.R. 2018. The Role of Islamic Financial Technology (FinTech ) Start-up. In Improving Financial Inclusion in Indonesia Case. Angsur.

Folkinshteyn, D., Lennon, M.M., Reilly, T. 2015. The Bitcoin mirage: An oasis of financial remittance. Journal of Strategic and International Studies, 10(2), 118-122.

Gassner, M., Lawrence, J. 2018. Fintech in Islamic Finance: Theory and Practice. Taylor and Francis Group. USA.

Gomber, P., Kauffman, R.J., Parker, C., Weber, B.W. 2018. On the Fintech revolution: interpreting the forces of innovation, disruption, and transformation in financial services. Journal of Management Information Systems, 35(1), 220-265.

Gomber, P., Koch, J., Siering, M. 2017. Digital Finance and FinTech: current research and future research directions. Journal of Business Economics, 87, 537-580.

Haddad, C., Hornuf, L. 2019. The emergence of the global fintech market: economic and technological determinants. Small Bus Econ 53, 81-105.

Haqqi, A. 2018. Strengthening Islamic Finance in South East Asia through Innovation: Islamic Fintech in Brunei Darussalam.

Hes, A., Jilkova, P. 2016. Position of Low-Cost Banks on the Financial Market in Czech Republic. European Research Studies Journal, 19(4), 42-52.

Ibrahim, M.A., Fisol, W.N.M., Haji-Othman, Y. 2017. Customer intention on Islamic home financing products: an application of the theory of planned behavior (TPB). Mediterranean Journal of Social Sciences, 8(2), 77-86.

IOSCO. 2017. IOSCO analyzes potential of tech-driven change in the securities market industry. Available at: https://www.iosco.org/news/pdf/IOSCONEWS451.pdf.

Irfan, H., Ahmed, D. 2019. Fintech: The opportunity for Islamic finance. In Fintech in Islamic Finance. Theory and Practice, 19-30. Routledge.

Jędrzejowska-Schiffauer, I., Schiffauer, P., Thalassinos, I.E. 2019. EU Regulatory Measures Following the Crisis: What Impact on Corporate Governance of Financial Institutions. European Research Studies Journal, 22(3), 432-456.

Khan, S.N., Rabbani, M.R. 2020. Artificial Intelligence and NLP based Chatbot as Islamic Banking and Finance Expert. 2020 International Conference on Computational Linguistics and Natural Language Processing (CLNLP 2020), Seoul, South Korea on July 20-22.

Khan, S.N., Usman, I. 2019. A model for English to Urdu and Hindi machine translation system using translation rules and artificial neural network. Int. Arab J. Inf. Technol., 16(1), 125-131.

Khan, S.N., Mishra, R.B. 2011. Translation rules and ANN based model for English to Urdu machine translation. INFOCOMP, 10(3), 36-47.

Khan, S.N., Mir, U., Shreem, S.S., Alamri, S. 2018. Translation Divergence Patterns 
Handling in English to Urdu Machine Translation. International Journal on Artificial Intelligence Tools, 27(05), 1850017.

Lacasse, R.M., Lambert, B., Khan, N. 2017. Blockchain technology-Arsenal for a Shariahcompliant financial ecosystem. Journal of Business and Economics.

Lacasse, R.M., Lambert, B., Nida, K.H.A.N. 2018. Islamic Banking-Towards a Blockchain Monitoring Process. Revue de Gestion et d'Économie, 6(1\&2), 33-46.

Laldin, M.A. 2018. FinTech and Islamic Finance. IFN Islamic Finance News, 15, 67.

Lee, I., Shin, Y.J. 2018. Fintech: Ecosystem, business models, investment decisions, and challenges. Business Horizons, 61(1), 35-46.

Loo, R.V. 2018. Making innovation more competitive: The case of Fintech. UCLA Law Review, 65, 232.

MacDonagh, M. 2016. Artificial Intelligence Set to Transform Regulatory Compliance. Banking Tech. Available at: https://www.bankingtech.com/2016/09/artificialintelligence-set-to-transform-regulatory-compliance/.

Meera, A. 2018. Cryptocurrencies from Islamic Perspectives: The Case of Bitcoin. Buletin Ekonomi Moneter Dan Perbankan, 20(4), 475-492.

Milian, E., Spinola, M., Carvalho, M. 2019. Fintechs: A Literature Review and Research Agenda. Electronic Commerce Research and Applications, 34, 100833. 10.1016/j.elerap.2019.100833.

Michalopoulos, G., Tsermenidis, K. 2018. Country Risk on the Bank Borrowing Cost Dispersion Within the Euro Area during the Financial and Debt Crises. International Journal of Economics and Business Administration, 6(4), 76-92.

Miskam, S., Shahwahid, F.M., Sholehuddin, N.B. 2018. Catching the Fintech Wave in Islamic Finance: Regulatory Approach for Malaysia. 4th Muzakarah Fiqh \& International Fiqh Conference (MFIFC 2018).

Miskam, S., Yaacob, A., Rosman, R. 2019. Fintech and Its Impact on Islamic Fund Management in Malaysia: A Legal Viewpoint. Oseni, U., Hassan, M. and Hassan, R. (Ed.) Emerging Issues in Islamic Finance Law and Practice in Malaysia, Emerald Publishing Limited, 223-246. https://doi.org/10.1108/978-1-78973-545-120191019.

Mohamed, H., Ali, H. 2018. Blockchain, Fintech, and Islamic Finance: Building the Future in the New Islamic Digital Economy: Walter de Gruyter GmbH \& Co KG.

Muneeza, A., Arshad, N.A., Arifin, A.T. 2018. The Application of Blockchain Technology in Crowdfunding: Towards Financial Inclusion via Technology. International Journal of Management and Applied Research, 5(2), 82-98.

Nakamoto, S. 2008. Bitcoin: A Peer-to-Peer Electronic Cash System. bitcoin.org.

Natoor, B. 2019. Islamic FinTech faces regulatory hurdles, Fitch Ratings says. Available at: https://ibsintelligence.com/ibs-journal/ibs-news/islamic-fintech-fitch/.

Niforos, M., Ramachandran, V., Rehermann, T. 2017. Block Chain: Opportunities for Private Enterprises in Emerging Market. Washington, D.C., International Finance Corporation, available at https://openknowledge.worldbank.org/handle/10986/28962.

Noordin, K.A. 2018. Islamic Finance: Is Cryptocurrency halal? The Edge, Malaysia.

Othman, A., Alhabshi, S., Kassim, S., Sharofiddin, A. 2019. The impact of cryptocurrencies market development on banks' deposits variability in the GCC region. Journal of Financial Economic Policy. At: https://doi.org/10.1108/JFEP-02-2019-0036.

Oxford Dictionary. http://www.oxforddictionaries.com/it/definizione/inglese/fintech.

Oziev, G., Yandiev, M. 2017. Cryptocurrency from Shari'ah Perspective. Available at SSRN: https://ssrn.com/abstract $=3101981$ or http://dx.doi.org/10.2139/ssrn.3101981. 
Oziev, G., Magomet, Y. 2018. Cryptocurrency from a Shari'ah Perspective. Al-Shajarah: Journal of the International Institute of Islamic Thought and Civilization (ISTAC) 23(2), 315-338.

https://journals.iium.edu.my/shajarah/index.php/shaj/article/view/748.

Polansek, T. 2016. CME, ICE prepare pricing data that could boost bitcoin. Reuters. PWC. 2019. Pwc Global FinTech Survey 2019. Available on: https://www.pwc.com/gx/en/industries/financial-services/fintech-survey/blurredlines.html.

Rabbani, M.R. 2020a. Financial Literacy Among the Private University Students in Kingdom of Bahrain. International Journal of Scientific and Technology Research, 9(3).

Rabbani, M.R., Qadri, F.A., Ishfaq, M. 2016. Service Quality, Customer Satisfaction and Customer Loyalty: An Empirical Study on Banks in India. VFAST Transactions on Education and Social Sciences, 11(2), 1-9.

Rabbani, M.R., Shahnawaz, A.J., Rahiman, H. 2020b. Analysis of Critical Barriers to Women Entrepreneurship in Bahrain: An Exploratory study. International Journal of Scientific and Technology Research, Vo. 9, Issue 3.

Romanova, I., Kudinska, M. 2017. Banking \& Fintech: A Challenge or Opportunity. Contemporary Studies in Economic and Financial Analysis, 21-35.

Rupeika-Apoga, R., Zaidi, H.S., Thalassinos, E.Y., Thalassinos, I.E. 2018. Bank Stability: The Case of Nordic and Non-Nordic Banks in Latvia. International Journal of Economics and Business Administration, 6(2), 39-55, DOI: 10.35808/ijeba/156.

Rusydiana, S.A. 2018. Developing Islamic Financial Technology in Indonesia. Hasanuddin Economics and Business Review, Vol. 2, No. 2, 143-152.

Saad, M.A., Fisol, W.N., Bin, M. 2019. Financial Technology (Fintech) Services in Islamic Financial Institutions. In International Postgraduate Conference 1-10.

Saadiqin. 2020. http://www.saadiqin.com/.

Saba, I., Rehana, K., Imran, S.C. 2019. FinTech and Islamic Finance-Challenges and Opportunities. Review of Economics and Development Studies, Volume 5, No. 4.

Saksonova, S., Kuzmina-Merlino, I. 2017. Fintech as Financial Innovation-The Possibilities and Problems of Implementation. European Research Studies Journal, 20(3A), 961973.

Sangwan, V.H., Prakash, P., Singh, S. 2019. Financial technology: a review of extant literature. Studies in Economics and Finance. https://doi.org/10.1108/SEF-07-20190270 .

Sanicola, L. 2019. What is FinTech? Huffington Post. Available online: https://www.huffpost.com/entry/what-isfintech_b_58a20d80e4b0cd37efcfebaa.

Satyawati, I., Suroso, S., Suryanto, T., Nurjannah, S.D. 2017. Does Financial Performance of Islamic Banking is better? Panel Data Estimation. European Research Studies Journal, 20(2A), 592-606.

Schindler, J. 2017. FinTech and Financial Innovation: Drivers and Depth. Finance and Economics Discussion Series. Doi: 10.17016/FEDS.2017.081.

Schueffel, P. 2016. Taming the beast: A scientific definition of fintech. Journal of Innovation Management, 4, 32-54. doi: 10.24840/2183-0606_004.004_0004.

Schwarcz, S.L. 2013. Regulating Shadows: Financial Regulation and Responsibility Failure. Lee Law Review, 1781-1825.

Shahnawaz, Thirunavukkarasu, K. 2019. Indexing Issues in Spatial Big Data Management. International Conference on Advances in Engineering Science Management \& Technology. Uttaranchal University, Dehradun, India, 14th - 15th March.

Shahnawaz, Astya, P. 2017. Sentiment analysis: Approaches and open issues. International 
Conference on Computing, Communication and Automation (ICCCA). doi:10.1109/ccaa.2017.8229791

Shahnawaz, Mishra, R.B. 2013a. Rule-based approach for handling of case markers in English to Urdu/Hindi translation. International Journal of Knowledge Engineering and Soft Data Paradigms, 4(2), 138-165. Inderscience Publishers, DOI:10.1504/IJKESDP.2013.058128

Shahnawaz, Mishra, R.B. 2013b. Statistical machine translation system for English to Urdu. International Journal of Advanced Intelligence Paradigms, 5(3), 182-203. Inderscience Publishers, DOI: 10.1504/IJAIP.2013.056421

Shahnawaz, Mishra, R.B. 2015. An English to Urdu translation model based on CBR, ANN and translation rules. International Journal of Advanced Intelligence Paradigms, $7(1), 1-23$.

Shahnawaz, M.R. 2011. ANN and rule-based model for English to Urdu-Hindi machine translation system. In Proceedings of National Conference on Artificial Intelligence and agents: Theory\& Application, AIAIATA 2011, 115-121.

Siswantoro, D., Handika, R., Mita, A.F. 2020. The requirements of cryptocurrency for money, an Islamic view. Heliyon, 6(1), e03235.

Skan, J., Lumb, R., Masood, S., Conway, S.K. 2014. The boom in global Fintech investment: A new growth opportunity for London. Retrieved from https://www.cbinsights.com/research-reports/Boom-in-Global-FinTechInvestment.pdf.

Thalassinos, I.E., Thalassinos, Y. 2018. Financial Crises and e-Commerce: How Are They Related. Available at SSRN: https://ssrn.com/abstract=3330169.

Thalassinos, I.E., Pintea, M., Raţiu, I.P. 2015a. The Recent Financial Crisis and Its Impact on the Performance Indicators of Selected Countries during the Crisis Period: A Reply. International Journal of Economics and Business Administration, 3(1), 3-20.

Thalassinos, I.E., Stamatopoulos, D.T. and Thalassinos, E.P. 2015b. The European Sovereign Debt Crisis and the Role of Credit Swaps. Chapter book in The WSPC Handbook of Futures Markets (eds) W. T. Ziemba and A.G. Malliaris, in memory of Late Milton Miller (Nobel 1990), 605-639. DOI: 10.1142/9789814566926_0020.

Thalassinos, I.E., Liapis, K. and Thalassinos, E.J. 2014. The role of the rating companies in the recent financial crisis in the Balkan and black sea area. Chapter book in Economic Crisis in Europe and the Balkans, 79-115, Contributions to Economics, Springer International Publishing, DOI: 10.1007/978-3-319-00494-5_6.

Thalassinos, I.E., Deceanu, L., Pintea, M. 2010. New Dimensions of Country Risk in the Context of the Current Crisis: A Case Study for Romania and Greece. European Research Studies Journal, 13(3), 225-236.

Thalassinos, I.E. 2008. Trends and Developments in the European Financial Sector. European Financial and Accounting Journal, 3(3), 44-61.

Thalassinos, I,E., Thalassinos, E.P. 2006. Stock Markets' Integration Analysis. European Research Studies Journal, 9(3-4), 3-14.

Tornjanski, V., Marinković, S., Săvoiu, G., Čudanov, M. 2015. A Need for Research Focus Shift: Banking Industry in the Age of Digital Disruption. Econophysics, Sociophysics \& other Multidisciplinary Sciences Journal, 5(3), 11-15.

Treleaven, P. 2015. Financial Regulation of Fintech. Journal of Financial Perspectives, 3(3).

Tsai, C.H., Peng, K.J. 2017. The FinTech Revolution and Financial Regulation: The Case of Online Supply-Chain Financing. Published online by Cambridge University Press.

Tsai, Chang-Hsien. 2016. Legal Transplantation or Legal Innovation? Equity Crowdfunding 
Regulation in Taiwan after Title III of the U.S. Jobs Act. Boston University International Law Journal 233-277.

Wijayanti, D.M., Pradipta, H. 2017. Sharia FinTech: Positive Innovation in Consumer Perspective. Paper presented at the International Seminar Academic Network on Competition Policy, Bali.

Wintermeyer, L. 2017. The Future of Islamic FinTech is Bright. https://www.forbes.com/sites/lawrencewintermeyer/2017/12/08/the-future-ofislamic-fintech-is-bright/\#684952e465fa.

Wintermeyer, L., Abdul, Haseeb Basit. 2017. The Future of Islamic FinTech Is Bright. Forbes. https://www.forbes.com/sites/lawrencewintermeyer/2017/12/08/the-futureof-islamic-fintech-is-bright/\#47e1b19a65fa.

Wonglimpiyarat, J. 2017. FinTech banking industry: a systemic approach. Foresight, Vol. 19, No. 6, 590-603. https://doi.org/10.1108/FS-07-2017-0026.

Yakubowski, M. 2019. Could Crypto be Compliant with Sharia Law? Avaialble at https://cointelegraph.com/news/could-crypto-be-compliant-with-sharia-law-expertsanswer.

Zahudi, Z.M., Amir, R.A.T.R. 2016. Regulation of Virtual Currencies: Mitigating the Risks and Challenges Involved. Journal of Islamic Finance, 5(1), 63-73.

Zhu, Z., Zhou, Z.Z. 2016. Analysis and outlook of applications of blockchain technology to equity crowdfunding in China. Financial Innovation, Vol. 2, No. 1, 29-36. 